\title{
Cardin's Whitefly, Metaleurodicus cardini (Back) (Insecta: Homoptera: Aleyrodidae: Aleurodicinae) ${ }^{1}$
}

Avas B. Hamon ${ }^{2}$

\section{Introduction}

Cardin's whitefly, Metaleurodicus cardini (Back), has been known in Florida since 1917. It was originally described from Cuba and was named for Professor Patricio Cardin. This whitefly is usually innocuous, but under some situations can become a damaging pest. These situations usually occur when something has disrupted the parasite/predator complex.

\section{Synonymy}

Aleurodicus cardini Back 1912, Canadian

Entomol. 44: 148-51.

Aleurodicus (Metaleurodicus) cardini Back; Quaintance and Baker 1913. p. 75-77.

Metaleurodicus cardini (Back); Bondar 1923. p. 81.

\section{Distribution}

Known from Gainesville to South Florida, and it is much more common in the subtropical areas. Foreign distribution includes Cuba, Bermuda, and Jamaica.

\section{Description}

Pupa: The pupal case is just short of $1 \mathrm{~mm}$ long and $0.6 \mathrm{~mm}$ wide. It is elongate oval in shape and elevated on a vertical marginal waxen fringe (Figure $1)$. The pupal case color is yellowish white and becomes semitransparent when empty. Parasitized pupal cases are blackish throughout or in spots (Back 1912). Dorsum of pupal case has five pairs of large compound pores with a reduced number of locules. Smaller pores with a star-shaped internal matrix are scattered over the dorsal surface. A row of bilocular wax pores are present around the dorsal submargin. The vasiform orifice is subcordate in outline, with the cephalic margin straight, and the operculum is somewhat rectangular in shape. The lingula is spatulate, slightly exserted and armed with four long setae (Quaintance and Baker 1913).

1. This document is EENY-153 (originally published as DPI Entomology Circular 316), one of a series of Featured Creatures from the Entomology and Nematology Department, Florida Cooperative Extension Service, Institute of Food and Agricultural Sciences, University of Florida. Published: September 2000. Revised: December 2003. This document is also available on Featured Creatures Website at http://creatures.ifas.ufl.edu. Please visit the EDIS Website at http://edis.ifas.ufl.edu. Additional information on these organisms, including many color photographs, is available at the Entomology and Nematology Department website at http://entnemdept.ifas.ufl.edu/.

2. Avas B. Hamon, Florida Department of Agriculture and Consumer Services, Division of Plant Industry, Gainesville, FL.

The Institute of Food and Agricultural Sciences (IFAS) is an Equal Opportunity Institution authorized to provide research, educational information and other services only to individuals and institutions that function with non-discrimination with respect to race, creed, color, religion, age, disability, sex, sexual orientation, marital status, national origin, political opinions or affiliations. U.S. Department of Agriculture, Cooperative Extension Service, University of Florida, IFAS, Florida A. \& M. University Cooperative Extension Program, and Boards of County Commissioners Cooperating. Larry Arrington, Dean 


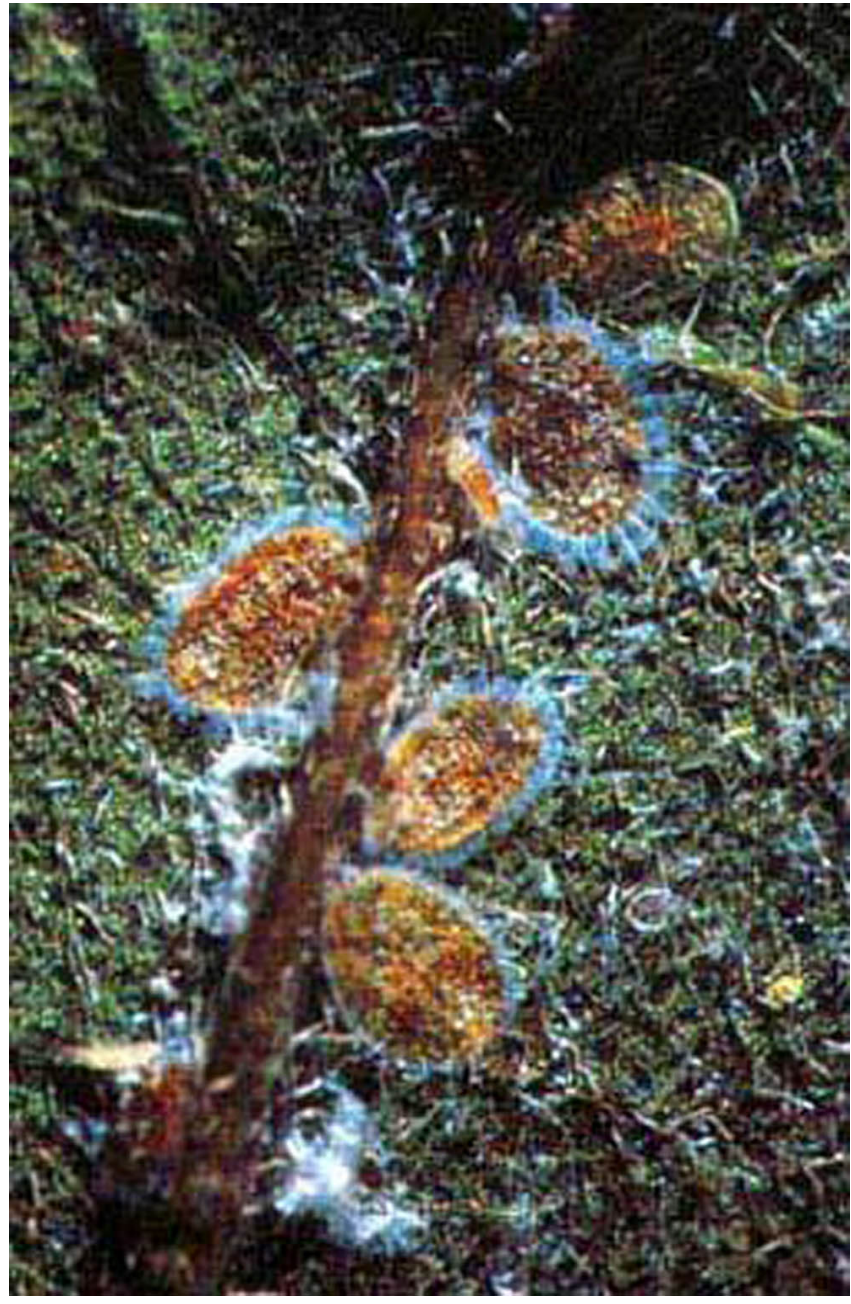

Figure 1. Pupal cases of Cardin's whitefly, Metaleurodicus cardini (Back). Credits: Division of Plant Industry

Adult: The adult is greenish yellow with a fine dusting of white wax (Figure 2). The wings are somewhat dusky with a conspicuous dark spot near the center of each wing. As females deposit eggs, a fine trail of fluffy white wax (Figure 3 ) is rubbed from a tuft of wax on the underside of the female abdomen.

\section{Diagnosis}

The adult is distinguished readily from all other whiteflies known in Florida by the distinct dark spot on each wing. The pupal case will require a microscope slide preparation. The pupa is separated from other Florida species by the four pairs of abdominal cup-shaped compound pores with reduced loculi, and the 5th pair on the cephalic segment. The only other species of this genus known in Florida, Metaleurodicus griseus (Dozier) (new combination),

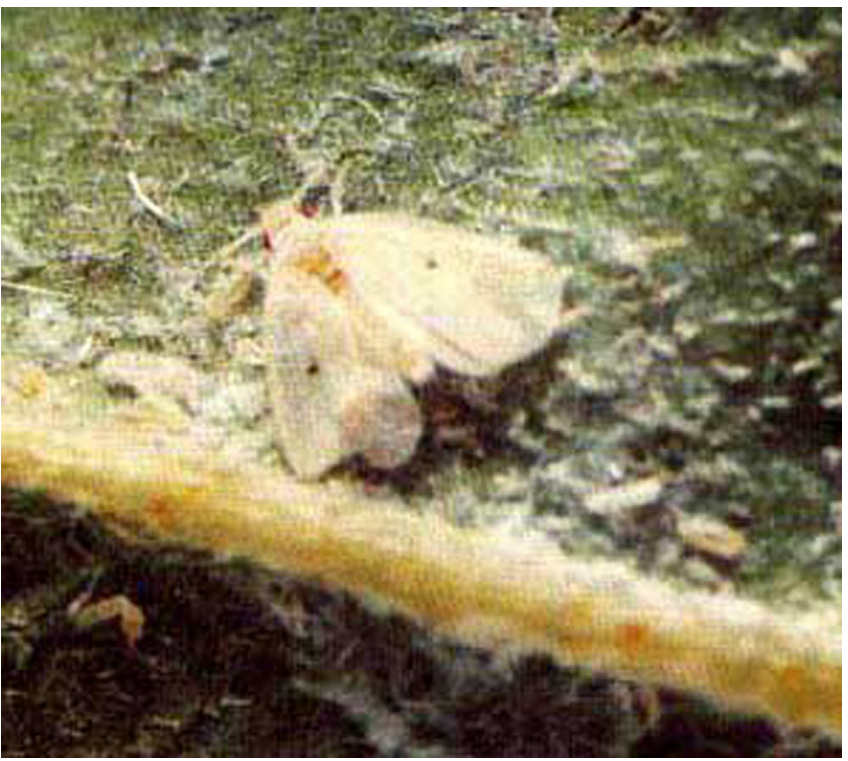

Figure 2. Adult Cardin's whitefly, Metaleurodicus cardini (Back). Credits: Division of Plant Industry

has six abdominal pairs of compound pores, and occurs only on Eugenia spp. in Florida.

A key that covers 16 species of whiteflies that may infest Florida citrus is available on the World Wide Web. The WWW key, developed by the Florida Department of Agriculture and Consumer Services' Division of Plant Industry, uses color photographs of nymphs to assist in identification. It is available at: http://www.doacs.state.fl.us/ pi/enpp/ento/ aleyrodi.htm.

\section{Hosts}

The most common host in Florida is Psidium guajava. Other hosts from the DPI files are: Citharexylum fruiticosum, Dipholis salicifolia, Duranta repens, Duranta sp., Eugenia sp., Malpighia glabra, Melaleuca quinquenervia, Paurotis wrightii, Pimenta dioica, and Plumeria sp. Additional hosts from the literature are: Citrus sinensis, Citrus sp., and Citharexylum spinosum (Mound and Halsey 1978).

\section{Survey and Detection}

Inspect the undersides of leaves for white fluffy wax trails, pupal cases, and adult whiteflies with a dark spot on each wing. This is only whitefly in Florida easily identified from the adult. 


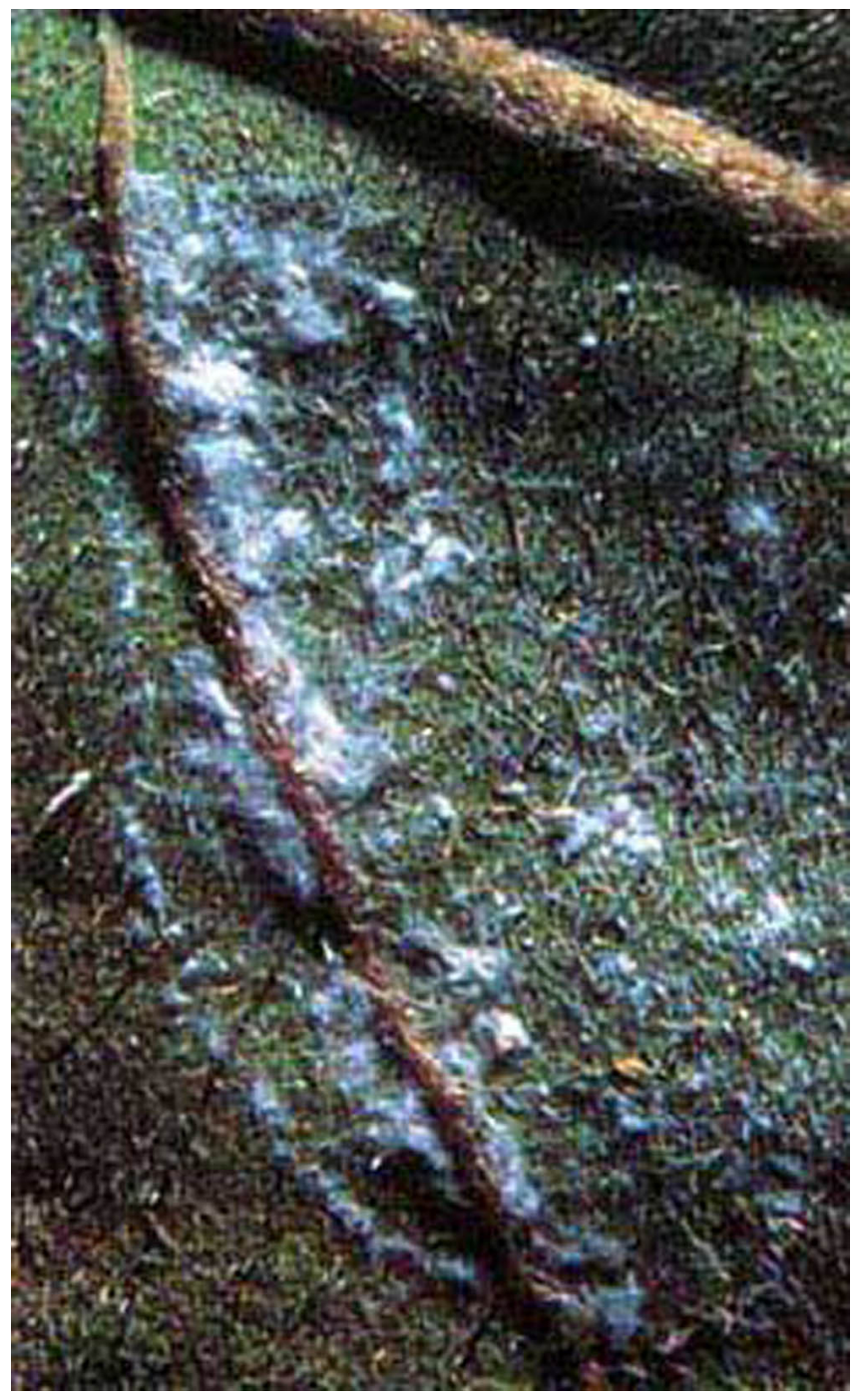

Figure 3. Fluffy wax trails deposited by adult female Cardin's whitefly, Metaleurodicus cardini (Back). Credits: Division of Plant Industry

\section{Management}

Whiteflies also are controlled by sprays applied primarily for control of scale insects. Spraying of commercial citrus exclusively for whitefly control is seldom practiced in Florida. Recommended control measures for commercial or dooryard citrus are significantly different. Please consult the specific management guide for your situation.

Citrus Management Guide for whiteflies in commercial groves

Control of whiteflies on Florida's dooryard citrus trees
It is important to note that spraying with copper for control of harmful fungal diseases will also inhibit growth of "friendly fungi" resulting in an increase in whitefly populations. Also, more than one application of sulfur per year can have an adverse effect on parasites. Spray oil has some insecticidal properties, but is primarily used to remove sooty mold which grows on the fruit and leaves.

\section{Selected References}

Back, E.A. 1912. Notes on Cuban whiteflies with descriptions of two new species. Canadian Entomol. 44: 145-153.

Bondar, G. 1923. Aleyrodidos do Brasil. Bahia: 81.

Evans, G.A. and A.B. Hamon. (5 November 2002). Whitefly taxonomic and ecological Web site: an on-line interactive catalog of the whiteflies (Hemiptera: Aleyrodidae) of the world and their parasites and predators.

http://www.fsca-dpi.org/homoptera_hemiptera/ Whitefly/whitefly_catalog.htm (13 November 2002).

Hamon, A.B. (1997). Whitefly of citrus in Florida. FDACS.

http://www.doacs.state.fl.us/ pi/enpp/ento/ aleyrodi.htm (8 September 2000).

Mound, L.A., and Halsey, S.H. 1978. Whitefly of the world. British Museum (Natur. Hist.) and John Wiley and Sons, Chichester. p. 244.

Quaintance, A.L., and Baker, A.C. 1913. Classification of the Aleyrodidae Part I. Tech. Ser. Bur. Ent. U.S. 27: 75-77. 